\title{
Intestinal cryptosporidiosis in HIV-infected patients in the department of infectious diseases
}

\author{
L Badoui", G Dabo, H Lamdini, A Oulad Lahcen, M Sodqi, L Marih, A Chakib, M Soussi, K Marhoum El Filali \\ From Abstracts from International Symposium HIV and Emerging Infectious Diseases 2014 \\ Marseille, France. 21-23 May 2013
}

\section{Introduction}

The Cryptosporidiosis is a gastrointestinal opportunistic parasitic disease is a major cause of diarrhea and malnutrition in patients infected with HIV. Its prevalence is estimated at $2.76 \%$. The aim was to determine the prevalence of intestinal Cryptosporidium in patients infected with HIV and to identify Cryptosporidium species in question.

\section{Materials and methods}

This is a retrospective study conducted 20 months in the department of Infectious Diseases. Cryptosporidium research was conducted by the Ziehl-Neelsen and modified by PCR. Data collection was made from computerized records.

\section{Results}

We collected 75 patients. The mean age of patients was 37 years old. The median $\mathrm{CD} 4$ was $62 \mathrm{cel} / \mathrm{mm}^{3}$. Intestinal cryptosporidiosis was indicative of HIV infection in 54 cases $(77 \%)$ and in 16 cases $(23 \%)$ they occurred at the waning of treatment failure. Cryptosporidia were isolated from 52 patients (69.3\%). Eight of them were gay. Consumption of raw milk and the presence of animals in the environment have been reported by more than two thirds of patients. Thirty five infected individuals were diarrhea, 12 had febrile abdominal pain. Cryptosporidium parvum was the species most frequently isolated. $80 \%$ of patients had progressed well $(n=60)$, and we recorded $20 \%$ of deaths $(n=15)$.

\section{Conclusion}

The prevalence of cryptosporidiosis is higher in patients infected with HIV. The strengthening of preventive measures is necessary especially as some of the identified species at risk of human transmission in hospitals.

Ibn Rochd University Hospital, Casablanca, Morocco
The prognosis of the disease remains in the absence of effective therapy, dark in refractory cases symptomatic treatment and HAART.

Published: 23 May 2014

doi:10.1186/1471-2334-14-S2-P52

Cite this article as: Badoui et al:. Intestinal cryptosporidiosis in HIV-infected patients in the department of infectious diseases. BMC Infectious Diseases 2014 14(Suppl 2):P52.
Submit your next manuscript to BioMed Central and take full advantage of:

- Convenient online submission

- Thorough peer review

- No space constraints or color figure charges

- Immediate publication on acceptance

- Inclusion in PubMed, CAS, Scopus and Google Scholar

- Research which is freely available for redistribution 